\title{
Groundwater Dependent Ecosystems: Classification, Identification Techniques and Threats
}

\author{
Derek Eamus, Baihua Fu, Abraham E. Springer, and \\ Lawrence E. Stevens
}

\begin{abstract}
This chapter begins by briefly discussing the three major classes of groundwater dependent ecosystems (GDEs), namely: (I) GDEs that reside within groundwater (e.g. karsts; stygofauna); (II) GDEs requiring the surface expression of groundwater (e.g. springs; wetlands); and (III) GDEs dependent upon sub-surface availability of groundwater within the rooting depth of vegetation (e.g. woodlands; riparian forests). We then discuss a range of techniques available for identifying the location of GDEs in a landscape, with a primary focus of class III GDEs and a secondary focus of class II GDEs. These techniques include inferential methodologies, using hydrological, geochemical and geomorphological indicators, biotic assemblages, historical documentation, and remote sensing methodologies. Techniques available to quantify groundwater use by GDEs are briefly described, including application of simple modelling tools, remote sensing methods and complex modelling applications. This chapter also outlines the contemporary threats to the persistence of GDEs across the world. This involves a description of the "natural" hydrological attributes relevant to GDEs and the
\end{abstract}

\footnotetext{
D. Eamus

National Centre for Groundwater Research and Training, and School of Life Sciences, University of Technology Sydney, PO Box 123, Sydney, NSW 2007, Australia

B. Fu $(\bowtie)$

National Centre for Groundwater Research and Training, and Fenner School of Environment and Society, Australian National University, Canberra, ACT 0200, Australia e-mail: Baihua.fu@anu.edu.au
}

\section{A.E. Springer}

School of Earth Sciences and Environmental Sustainability, Northern Arizona University, P.O. Box 4099, Flagstaff, AZ 86011, USA

\section{L.E. Stevens}

Springs Stewardship Institute, Museum of Northern Arizona, 3101 N. Ft. Valley Rd, Flagstaff, AZ 86001, USA 
processes that lead to disturbances to natural hydrological attributes as a result of human activities (e.g. groundwater extraction). Two cases studies, (1) Class III: terrestrial vegetation and (2) Class II: springs, are discussed in relation to these issues.

\subsection{Introduction}

In order to sustainably manage groundwater in a truly integrated manner consideration needs to be given to the interaction of groundwater with ecology. Groundwater interacts with multiple classes of biome, including stygofauna of aquifers, rivers relying on base flow (the discharge of groundwater into rivers) and terrestrial ecosystems. Management plans that do not include such consideration are likely to negatively impact these groundwater dependent ecosystems.

In this chapter, we focus on the links between ecology and groundwater availability, rather than on groundwater resources and human demand. This is because we feel that environmental allocations of groundwater have generally received less attention than allocations to human demands and because we identify four important knowledge gaps to the sustainable management of environmental allocations of groundwater. These are:

1. How do we know where a GDE is in the landscape? If we do not know where they are, we cannot manage them and allocate groundwater resources appropriately.

2. How much groundwater is used by a GDE? If we do not know how much groundwater is used, we cannot allocate an appropriate quantity of the resource.

3. What are the threats to GDEs? Only by understanding the threats to GDEs can we ensure their sustainable management.

4. What are the likely responses of GDEs to over extraction of groundwater? Without knowing what to measure, we cannot regulate groundwater extraction in ways that do not negatively impact on GDEs.

\subsection{Classes of GDEs and Relevant Groundwater Attributes}

\subsubsection{GDE Classification}

Hatton and Evans (1998) were perhaps the first to attempt to categorise GDEs systematically. They recognised five classes of ecosystem dependency on groundwater:

1. Ecosystems entirely dependent on groundwater; or obligate GDEs. In these communities only small changes in groundwater availability or quality result 
in the total loss of the current ecosystem structure and function. Examples of entirely dependent ecosystems include the mound spring systems of the Great Artesian Basin of eastern Australia, karstic groundwater ecosystems of Western Australia and riparian vegetation along streams in central Australia.

2. Ecosystems highly dependent on groundwater. In these communities small to moderate changes in groundwater availability result in significant changes in ecosystem structure and function. Examples of highly dependent ecosystems in Australia include: Melaleuca swamp forests and woodlands of tropical northern Australia, base flow dependent ecosystems of temperate Australia and the damp lands of the Swan Coastal Plain.

3. Ecosystems with proportional dependence on groundwater. Such ecosystems do not exhibit the threshold-type responses of (1) and (2) above. As groundwater availability or quality changes, there is a proportional response in ecosystem structure and function and distribution. Examples include base flow and permanent lake ecosystems.

4. Ecosystems that are opportunistic users of groundwater. In these ecosystems groundwater has a significant role in their water balance occasionally and reliance is not obligate (so-called facultative dependency). Examples of opportunistic ecosystems include swamp forests of coastal floodplains along the fringe of the south-east uplands and Jarrah forests and Banksia woodlands of Western Australia.

5. Ecosystems that appear to be groundwater dependent, but are in fact entirely rain fed or dependent only on surface water flows. Examples of this type include seasonal floodplain lakes on small creeks in northern Australia and terminal drainage basin lakes in the Central Lowlands.

There are two major problems with this classification system. First, the determination of the degree of dependency is difficult and requires many years of study of a site. Establishing that an ecosystem is only an opportunistic user of groundwater may require a decade of waiting before a drought occurs and groundwater dependency becomes expressed. Second, establishing the presence or absence of a threshold response is extremely difficult and time consuming. Consequently, a simplified classification system was proposed by Eamus et al. (2006):

(I) Aquifer and cave ecosystems where stygofauna reside. This class also includes the hyporheic zones of rivers and floodplains.

(II) Ecosystems reliant on surface expression of groundwater. This includes base flow rivers, streams and wetlands, springs and estuarine seagrasses.

(III) Ecosystems reliant on sub-surface presence of groundwater within the rooting depth of the ecosystem (usually via the capillary fringe).

Application of this simple classification scheme assists managers in identifying the correct techniques for assessing GDE structure, function and management regime (Eamus et al. 2006). This classification scheme was recently adopted in the Australian National Atlas of Groundwater Dependent Ecosystems. 


\subsubsection{Classification of Springs Ecosystems as GDEs}

Springs occur in geomorphic settings that are far more complex than those of most wetlands, emerging from hill slopes, cliff faces, and beneath other bodies of water. Adding to their complex emergence environment, springs often support a wide array of microhabitats not observed in wetlands. The "sphere" into which the aquifer discharges was initially described by Meinzer (1923), and then simplified by Hynes (1970) into three classes: rheocrene (channel emergence), limnocrene (pool emergence), and helocrene (wet meadow emergence).

Springer et al. (2008) and Springer and Stevens (2009) reviewed literature and expanded this historical scheme to include 12 spheres of discharge of terrestrial springs, including: (1) springs that emerge in caves, (2) exposure springs, (3) artesian fountains, (4) geysers, (5) gushets, (6) contact hanging gardens, (7) helocrene wet meadows, (8) hill slope springs, (9) hypocrene buried springs, (10) limnocrene surficial lentic pools, (11) mineralized mounds, and (12) rheocrene lotic channel floors. This classification provides a more precise lexicon with which to describe groundwater emergence function in relation to ecosystem landform configuration and distribution.

Geomorphological variation among the 12 terrestrial springs types of Springer and Stevens (2009) leads to predictable variation in spring's vegetation, habitat structure, plant and faunal diversity, and ecosystem structure and function (Griffiths et al. 2008). For example, helocrene springs are typically dominated by wetland graminoid and shrub species, with little canopy cover by trees. Many hill slope springs typically occupy a position on the landscape where groundwater discharge has created a shallow concave depression due to low discharge rates winnowing away fine-grained sediments or groundwater sapping to create spring dependent headwater theatres for channels (Laity and Malin 1985; Meinzer 1923).

\subsubsection{Relevant Groundwater Attributes}

The persistence of GDEs relies on suitable groundwater attributes. Identifying these attributes is essential as this can help establish groundwater management targets and monitoring strategies (Kreamer et al. 2014). In general, the following groundwater attributes are important for GDEs (Clifton and Evans 2001):

1. Depth-to-groundwater, for unconfined aquifers;

2. Groundwater pressure - hydraulic head and its expression in groundwater discharge, for confined aquifers;

3. Groundwater flux - flow rate and volume of groundwater supply; flow direction;

4. Groundwater quality - including groundwater salinity, acidity and the concentrations of nutrients and pollutants. 
Importance of groundwater attributes to GDEs

\begin{tabular}{|c|c|c|c|c|}
\hline $\begin{array}{l}\text { Class I GDEs } \\
\text { (e.g. } \\
\text { woodlands) }\end{array}$ & $\begin{array}{l}\text { - Accessible water at } \\
\text { root zones; } \\
\text { - Prevent water-logging. }\end{array}$ & & $\begin{array}{l}\text { - Sustain water uptake } \\
\text { rate. }\end{array}$ & $\begin{array}{l}\text { Maintain suitable } \\
\text { chemical composition } \\
\text { in water supply. }\end{array}$ \\
\hline $\begin{array}{l}\text { Class II GDEs } \\
\text { (e.g. } \\
\text { wetlands, } \\
\text { streams) }\end{array}$ & $\begin{array}{l}\text { Provide wetness or } \\
\text { water-logged } \\
\text { environment; } \\
\text { - Prevent activation of } \\
\text { acid sulphate soil; } \\
\text { - Maintain hydraulic } \\
\text { gradient for } \\
\text { groundwater discharge. }\end{array}$ & $\begin{array}{l}\text { Sustain } \\
\text { groundwater } \\
\text { discharge to } \\
\text { springs. }\end{array}$ & $\begin{array}{l}\text { - Sustain above ground } \\
\text { wetness (wetlands); } \\
\text { - Sustain base flow; } \\
\text { - Prevent salt water } \\
\text { intrusion } \\
\text { (estuarine/coastal } \\
\text { environment). }\end{array}$ & $\begin{array}{l}\text { Maintain suitable } \\
\text { chemical composition } \\
\text { in water supply and } \\
\text { living environment. }\end{array}$ \\
\hline $\begin{array}{l}\text { Class III GDEs } \\
\text { (e.g. cave } \\
\text { systems) }\end{array}$ & $\begin{array}{l}\text { - Provide living habitat; } \\
\text { Maintain groundwater } \\
\text { stratification. }\end{array}$ & & $\begin{array}{l}\text { - Supply organic matter } \\
\text { and oxygen. }\end{array}$ & $\begin{array}{l}\text { - Maintain suitable } \\
\text { chemical composition } \\
\text { in living environment. }\end{array}$ \\
\hline & Depth & Pressure & Flux & Quality \\
\hline
\end{tabular}

\begin{tabular}{|c|c|c|}
\hline $\begin{array}{l}\text { Agricultural } \\
\text { practices }\end{array}$ & $\begin{array}{l}\text { - Reduced groundwater level/pressure due to } \\
\text { excessive groundwater extraction to support } \\
\text { agricultural development; } \\
\text { - Reduced groundwater recharge due to surface } \\
\text { water pumping for irrigation; } \\
\text { - Water-logging due to vegetation clearing and } \\
\text { poorly managed irrigation. }\end{array}$ & $\begin{array}{l}\text { - Groundwater contamination from fertilisers, } \\
\text { pesticides and other agricultural chemicals. } \\
\text { - Soil and water salinisation due to vegetation } \\
\text { clearing and excessive irrigation. }\end{array}$ \\
\hline $\begin{array}{l}\text { Urban and } \\
\text { industrial } \\
\text { development }\end{array}$ & $\begin{array}{l}\text { Reduced groundwater level/pressure due to } \\
\text { excessive groundwater extraction to support } \\
\text { urban and industrial development. }\end{array}$ & $\begin{array}{l}\text { - Ground water contamination from urban facilities, } \\
\text { landfills, fertilisers and pesticides (e.g. for gardens } \\
\text { and parks), stormwater/sewage disposal, and } \\
\text { other industrial chemicals. }\end{array}$ \\
\hline $\begin{array}{l}\text { Mining } \\
\text { activities }\end{array}$ & $\begin{array}{l}\text { Reduced level, pressure and flux due to mine } \\
\text { dewatering; } \\
\text { Reduced level due to channel incision (e.g. } \\
\text { gravel mining) }\end{array}$ & $\begin{array}{l}\text { - Change in groundwater stratification due to } \\
\text { dewatering; } \\
\text { - Groundwater contamination from tailings dams; } \\
\text { - Groundwater contamination through leaching of } \\
\text { acidic or toxic crushed rock storage sites; } \\
\text { - Groundwater contamination after mine closure, } \\
\text { due to water table rise and mine flooding. }\end{array}$ \\
\hline $\begin{array}{l}\text { Plantation } \\
\text { forestry }\end{array}$ & $\begin{array}{l}\text { - Reduced groundwater recharge and surface } \\
\text { flow; } \\
\text { - Increased groundwater discharge. }\end{array}$ & \\
\hline
\end{tabular}

Fig. 13.1 Importance of groundwater regime (depth-to-groundwater and groundwater pressure and flux) and quality on different classes of GDEs and the anthropogenic threats

Importance of these attributes to GDEs is summarised in Fig. 13.1. Depth-togroundwater (from the land surface) is perhaps one of the most important groundwater attributes for GDEs (Eamus et al. 2006). This is particularly the case for terrestrial ecosystems that rely on sub-surface provision of groundwater. Depth-togroundwater, with particular reference to the distance between the capillary fringe 
above the water table and plant roots, directly determines groundwater availability to vegetation. An increased depth-to-groundwater may lead to reduced plant growth, mortality and change in species compositions (Shafroth et al. 2000). Lowering a water table can also lead to loss of habitat for cave and aquifer ecosystems (Boulton et al. 2003; Heitmuller and Reece 2007). On the other hand, a rising water table may disadvantage those species vulnerable to water-logging and lead to succession to different plant communities (Naumburg et al. 2005). Changes in water table depth, coupled with other environmental factors, can also result in groundwater contamination. For example, lowering a water table beneath acid sulphate soils leads to oxidation of pyrite and subsequent acidification of the shallow aquifer (Ritsema et al. 1992; Nath et al. 2013).

Groundwater flux is important for Classes II and III GDEs because it sustains water uptake by vegetation (Shafroth et al. 2000). Reduced groundwater pressure and flux cause reduced groundwater discharge and subsequently reduced surface water availability to wetlands and GDEs that depend on base flow and springs (Zektser et al. 2005). In estuary or coastal areas reduced groundwater flux leads to seawater intrusion and contamination of coastal freshwater aquifers (Jayasekera et al. 2011; Lambrakis 1998), thereby reducing groundwater quality. For cave and aquifer ecosystems, appropriate groundwater flux is important to maintain a supply of organic matter and oxygen (Hancock et al. 2005) to stygofauna contained within these systems. Groundwater quality is critical for all types of GDEs to maintain suitable chemical composition in water supply and/or living environment. In some areas, groundwater is hydrochemically stratified. Disturbing the stratification may cause the chemical composition to be unsuitable for the associated aquifer ecosystems.

Depth-to-groundwater and groundwater pressure and flux naturally fluctuate. In unconfined aquifers, short-term fluctuations naturally occur in response to timevarying uptake of water by vegetation; whereas longer term fluctuations often reflect time-varying groundwater recharge as a result of wet and dry season cycles. GDEs that are developed at naturally highly fluctuating areas (e.g. areas with strong climatic seasonality) generally have adapted to the fluctuations of groundwater regime and hence can be more resilient to change in groundwater regime than those developed from areas with more constant regime. For example, in the Howard River catchment of the Northern Territory of Australia, natural intra-annual variation in groundwater depth is approximately $8 \mathrm{~m}$ (Cook et al. 1998). This large variation (arising through a combination of wet and dry season variation in rainfall, lateral sub-surface flow of groundwater to the Howard River and evapotranspirational discharge) is accommodated through changes in landscape leaf area index (LAI) and root depth.

These groundwater attributes can be altered due to human activities. The contemporary threats to the persistence of GDEs, including the processes that lead to disturbances to natural hydrological attributes as a result of human activities (e.g. groundwater abstraction), are described in Sect. 13.5. 


\subsection{Identifying GDEs}

Identifying the location of GDEs and assessing their dependency on groundwater is the vital first step to managing them. However, identifying their location across a landscape is often difficult, time-consuming and hence expensive and always requires a high level of technical expertise. In this section, a range of techniques that can be used to assist in this are discussed.

\subsubsection{Inferential Methods to Determine GDEs}

Early assessments of groundwater dependency frequently relied on inference (Clifton and Evans 2001; Eamus et al. 2006). Thus, answers in the affirmative to one or more of the following can be taken as supporting the hypothesis that at least some species in an ecosystem are using groundwater.

1. Does a stream/river flow all year, despite long periods of low or zero rainfall (and thus zero surface flows)?

2. For estuarine systems, do salinity levels fall below that of seawater in the absence of surface water inputs?

3. Does the total flux in a river increase downstream in the absence of inflow from a tributary or surface flow?

4. Are water levels in a wetland maintained during extended dry periods?

5. Is groundwater discharged to the surface for significant periods of time each year? If such a resource is present, evolution will ensure that some species will be using it.

6. Is the vegetation associated with the surface discharge of groundwater different (in terms of species composition, phenological pattern, leaf area index or vegetation structure) from vegetation close-by but which is not accessing this groundwater?

7. Is the annual rate of transpiration by vegetation at a suspected GDE significantly larger than annual rainfall at the site and the site is not a run-on site?

8. Are plant water relations (especially pre-dawn and mid-day water potentials and transpiration rates) indicative of less water stress (water potentials closer to zero; transpiration rate larger) than vegetation located nearby but not accessing the groundwater discharged at the surface? The best time to assess this is during rain-less periods.

9. Does the water balance of a site indicate that the sum of water-use plus interception loss plus run-off plus deep drainage is significantly larger that annual rainfall plus run-on?

10. Is occasional (or habitual) groundwater release at the surface associated with key developmental stages of the vegetation (such as flowering, germination, seedling establishment)? 
11. Does groundwater and hydrological modelling suggest that groundwater is either discharging to the surface or located within the likely rooting depth of the vegetation?

12. Is groundwater or the capillary fringe above the water table present within the rooting depth of any of the vegetation?

13. Does a proportion of the vegetation remain green and physiologically active (principally, transpiring and fixing carbon, although stem diameter growth or leaf growth are also good indicators) during extended dry periods of the year?

14. Within a small region (and thus an area having the same annual rainfall, temperature and vapour pressure deficit) and in an area not having access to run-on or stream or river water, do some ecosystems show large seasonal changes in leaf area index whilst others do not?

15. Are seasonal changes in groundwater depth larger than can be accounted for by the sum of lateral flows and percolation to depth (that is, is vegetation a significant discharge path for groundwater; (Cook et al. 1998))? Clearly, if the error terms in the estimation of lateral flow and percolation to depth are of similar magnitude or greater than the rate of vegetation water, this method may not be appropriate.

Affirmative answers to one or more of these questions leads to the inference that the system is a GDE. However, this does not provide any information about the nature of the dependency (obligate or facultative) nor about the groundwater regime (e.g. timing of groundwater availability, volume utilised, location of surface expression, the pressure of the groundwater aquifer required to support the surface discharge of groundwater) needed to support the ecosystem.

\subsubsection{Hydrological Indication of GDE Status}

In shallow unconfined aquifers where roots of vegetation are directly accessing the water table (via the capillary zone usually), it is possible to discern the diurnal pattern of vegetation water-use in sub-daily fluctuations in the depth-to-groundwater (Gribovszki et al. 2010). Although diurnal changes in atmospheric pressure or temperature (which induce changes in water volume, evaporation and condensation) and inputs of rainfall can cause changes in groundwater depth, it is still possible to identify and sometimes quantify the extraction of groundwater through transpiration (Gribovszki et al. 2010).

White, in 1932, was possibly the first to use sub-daily changes in groundwater depth to quantify transpiration use of groundwater (White 1932). An idealised representation of the deil pattern of groundwater depth in a shallow unconfined aquifer is shown in Fig. 13.2.

The solid continuous oscillating curve represents the cycle of groundwater drawdown (because of ET) during the day followed by the rebound of the water table when ET returns to zero (assuming no nocturnal transpiration) at night. The dashed straight line (with slope $=r$ ) is used to estimate the amount of water 
Fig. 13.2 A schematic representation of changes in depth-to-groundwater due to vegetation transpiration

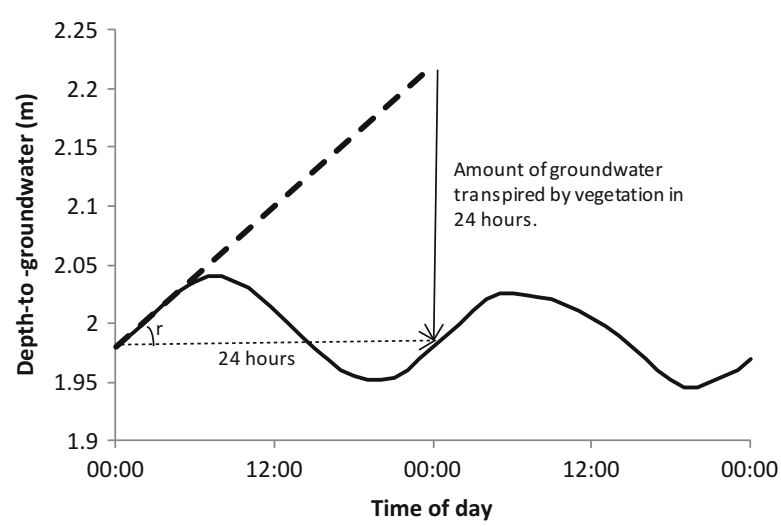

transpired by vegetation in $24 \mathrm{~h}(0: 00 \mathrm{~h}$ to $0: 0024 \mathrm{~h}$ later; indicated by the horizontal dotted arrow). This is represented by the vertical arrow which is the difference between the groundwater depth that would have occurred in the absence of vegetation water-use and the observed groundwater depth. By applying this methodology it is possible to identify the location of a GDE, thereby providing the first step in managing both the groundwater and the dependent ecology.

Lautz (2008) provides a detailed analysis of groundwater use using the White method of analyses of sub-daily changes in groundwater depth. She shows that spatial differences in groundwater use can be explained by differences in vegetation type (riparian wetland and grassland) and specific yield of the aquifer. As expected, the ratio of groundwater-to-soil water extraction increased as soil moisture content declined as a function of time since rain.

\subsubsection{Geochemical Indication of GDE Status: Tracers and Isotopes}

Geochemical studies, particularly isotopic analyses of water samples, can be used to distinguish groundwater sources from other water sources (e.g. atmospheric, soil water, or stream water sources), and used to identify source areas and groundwater residence time (e.g. Winograd et al. 1998; Monroe et al. 2005). Mineral deposition and helium isotope expression through groundwater discharge also can indicate groundwater discharge (Crossey and Karlstrom 2012), as attested to by the presence of certain plant species and invertebrates. For base flow systems (that is, rivers and streams showing significant flows during periods of zero surface or lateral flows), measurements of the chlorofluorocarbon, magnesium or radon concentrations of river and groundwater supply can identify and quantify the amount and timing of groundwater inflows into the river (Cook et al. 2003).

Stable isotopes (such as deuterium $\left({ }^{2} \mathrm{H}\right)$ and ${ }^{18} \mathrm{O}$ ) can be used for these systems too, as can artificial labelling with tracers, such as lithium. When tracers are added to the groundwater, the subsequent uptake into vegetation is usually conclusive 


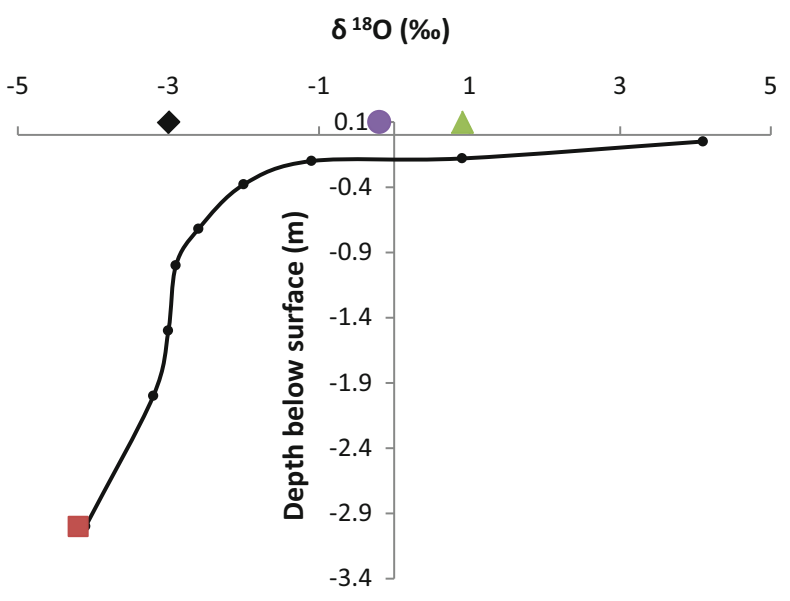

Fig. 13.3 An example of the use of ${ }^{18} \mathrm{O}$ analyses of xylem water, soil water and groundwater in a study of multiple species growing in northern Yucatan (Mexico). The ${ }^{18} \mathrm{O}$ content of soil declines with depth through the soil profile and eventually groundwater is reached (at $3 \mathrm{~m}$; brown square). The xylem ${ }^{18} \mathrm{O}$ content of three species (Ficus spp. green triangle; Spondias spp. purple circle; and Talisia spp. black diamond) is also presented. Ficus was the least reliant on groundwater whilst Talisia was the most reliant (Redrawn from Querejeta et al. 2007)

proof that access by that vegetation is occurring. However, the presence of a tracer in a shallow rooted species can occur if neighbouring deep rooted species exhibit hydraulic lift and the shallow rooted plants then "harvest" this water (Caldwell et al. 1998). When a close match between groundwater isotope composition and xylem isotope composition is made, we can conclude that the vegetation is using groundwater.

Direct evidence that vegetation is using groundwater can be obtained by comparing the stable isotope composition of groundwater, soil water, surface water (where relevant) and vegetation xylem water (Kray et al. 2012; Lamontagne et al. 2005; O'Grady et al. 2006; Thorburn et al. 1993; Zencich et al. 2002; Spałek and Pro-ków 2011). A direct comparison of periodic measurements was made by Hunt et al. (1996) who showed that time integration provided by measurements of isotopic composition was a valuable tool that provide insights not available from non-isotopic techniques. Where sufficient variation in isotopic composition among these sources occurs then it is possible to identify the single or the most dominant source of water being used by different species at different times of year (Zencich et al. 2002). An example of the use of ${ }^{18} \mathrm{O}$ isotope analyses of xylem water, soil water and groundwater is shown in Fig. 13.3.

Mixed-member models are available that allow estimation of the relative contribution of multiple sources of water to the water absorbed by roots (Phillips and Gregg 2003; Kolb et al. 1997). Thus the use of stable isotopes can provide information about spatial and temporal variation in groundwater dependency and rates of groundwater use within and between species and ecosystems. Application 
of stable isotope analyses to quantify the rate of water use is discussed in Sect. 13.4.4.

\subsubsection{Geomorphological Indicators of GDE Status}

The various springs spheres of discharge (springs types) generate characteristic geomorphology and soils that may indicate groundwater dependence. Travertine mound-forming springs and hanging gardens are obvious examples of distinctive GDE geomorphology. Aerial photographic analysis of spring channels is commonly used to plan springs restoration projects (e.g. Ramstead et al. 2012). Because the geometry of springs channels is often erratic and non-sinuous (Griffiths et al. 2008), detection of such channel configuration is one indication of a spring flow domination, rather than surface flow domination (Springer et al. 2008). In hypocrenes, excavation of shallow wells or soil pits/cores can help identify groundwater sources, and among other springs types, discrete particle size arrays may result from constancy of discharge from some types of springs.

Geochemical deposits such as travertine commonly indicate groundwater dependence in mound-forming, hypocrene, geyser, and other springs types. Montezuma Well, the massive travertines along the Colorado River, and collapsed travertine mounds in the Tierra Amarilla region of northern New Mexico, are all examples of springs-related landforms (Crossey and Karlstrom 2012; Johnson et al. 2011; Newell et al. 2005).

In arid regions, organic soil development at springs can be extensive, distinctive, and dateable using radiocarbon techniques. Groundwater dependent peat deposits may be massive and can persist for millennia (e.g. Haynes 2008). Peat deposits more than $2 \mathrm{~m}$ thick were mined commercially in the Upper Carson Slough in Ash Meadows, a spring fed tributary of the upper Amargosa River basin in southern Nevada (McCracken 1992). If site geomorphology has not been much altered, these distinctive groundwater-generated landforms and soils features may remain identifiable, even if the aquifer has been largely dewatered.

\subsubsection{Biotic Assemblages as GDE Status}

Throughout the world, both in terrestrial and subaqueous settings, springs are widely known to support unique aquatic and wetland plant species and unique assemblages. In one of hundreds of examples of unusual springs-dependent plant species, Spałek and Pro-ków (2011) reported a highly isolated population of springs-dependent Batrachium baudotii (Ranunculaceae) in a karst spring in central Poland. The few remaining mound springs between Guildford and Muchea in Western Australia support restricted wetland graminoid plant assemblages, with Cyperaceae, Juncaceae, and Restionaceae, as well as flooded gum (Eucalyptus rudis) and bracken fern (Pteridium esculentum) (Blyth and English 1996). 
In addition to springs-dependent aquatic and wetland species, the dendrochronology of trees from the periphery of springs also may be useful for establishing flow perenniality. Melis et al. (1996) used such data to evaluate flow variability of springfed Havasu Creek in Grand Canyon, reporting that the Fraxinus velutina cores revealed complacency of growth, indicating perennial flow over 80 years.

Surface-dwelling groundwater dependent species that indicate long-term groundwater flow perenniality include several groups of plants, invertebrates, fish, and amphibians. Among the plants in North America, such springs-dependent species are selected sedges (Caryophyllaceae), rushes (Juncaceae), and herbaceous taxa (e.g. some Primulaceae, Toxicoscordion spp., Flaveria mcdougallii). Among invertebrates, hydrobiid spring snails commonly are restricted to springs sources and channels, particularly the Pyrgulopsis and Tryonia (Hershler 1998, 2014), as are some members of the aquatic beetle families Elmidae and Dryopidae (Shepard 1993). In our studies of montane springs in the American Southwest, chloroperlid stoneflies and turbellarian flatworms are often springs-dependent species in coolcold natural waters. Among North American fish, the pupfishes (Cyprinodontidae) and goodeid topminnows (Goodeidae) are often springs-dependent, and often are tightly restricted to individual springs (e.g. Minckley and Deacon 1991; Unmack and Minckley 2008). Among southwestern amphibians, populations of native ranid frogs in the genus Lithobates (Rana) are often associated with groundwater dependent wet meadows (cienegas, GDE fens). The giant aquatic hellbender salamander, Cryptobranchus alleganiensis bishopi only occurs in clear water springfed stream segments in the Ozarks. Several turtle species in eastern North America hibernate on the periphery of coldwater springs, where they are cooled but are protected from freezing (Nickerson and Mays 1973; Ernst and Lovich 2009).

\subsubsection{Historical Documentation of GDE Status}

Historical documentation is often useful for establishing GDE status and the perenniality of springs flow. Many sources of historical information may be available for such documentation, such as historical photographs and diaries, and interviews with long-term stewards and community elders. Such historical information can be quite valuable for understanding change through time; however, locating, determining the validity of such information, and compiling and interpreting the information can be challenging.

\subsubsection{Remote Sensing}

Detection of GDEs through remote sensing (RS) includes the use of infrared and other aerial thermal imaging, and has been used successfully to locate groundwater sources, particularly during seasons with the greatest temperature differences between air and groundwater temperatures. Remote sensing (RS) provides a rapid and spatially extensive technique to assess vegetation structure (e.g. leaf area index, 
basal area), vegetation function (e.g. canopy temperature, rates of evapotranspiration and "greenness") and relationships amongst climate variables, vegetation function and vegetation structure.

An underlying conceptual model for the application of RS to identifying the location of GDEs has been that of "green islands". In this approach, the structure or function of one pixel in a RS image is compared to that of an adjacent pixel. If a GDE covers a significant fraction of the area of one pixel but not the other, it is assumed that during prolonged dry periods the structure/function of the two vegetation types will diverge. This is because the vegetation accessing groundwater is not experiencing soil dryness to the same extent (if at all) as the vegetation that is not accessing groundwater. Under the green islands conceptual model, assessments of vegetation structure or function are determined for the site of interest and compared to adjacent "control" sites, either at a single time, or preferentially, across several contrasting times (comparisons across "wet" and "dry" periods usually).

In the United States, aerial thermography surveys of the largest of Florida's springs, Silver Springs, were conducted along the spring-fed run out channel and detected new spring orifices over $1200 \mathrm{~m}$ below the first source (Munch et al. 2006). Remote sensing techniques can be successfully used in low-gradient terrain that is not covered by dense vegetation. The U.S. Forest Service conducted remote sensing analysis for fens in the Rocky Mountains to detect fens (U.S. Forest Service 2012), reporting good success in locating large fens that were exposed. However, a similar remote sensing effort in the topographically complex Spring Mountains of southern Nevada detected fewer than $50 \%$ of the more than 200 springs in that range (U.S. Forest Service 2012).

\subsubsection{Application of Vegetation Indices Derived from RS}

Münch and Conrad (2007) examined three catchment areas in the northern Sandveld of South Africa. They used Landsat imagery to identify the presence/ absence of wetlands and combined this with GIS terrain modelling to determine whether GDEs could be identified using a landscape "wetness potential". It is important to note that this application focused on Class II GDEs - those reliant on a surface expression of groundwater. They applied the "green island" philosophy and compared the attributes of potential GDEs with the attributes of surrounding land covers at three contrasting times: July when rains started at the end of a dry year, August, in the winter of a wet year and at the end of a dry summer. They concluded that RS data could be used to classify landscapes and when this was combined with a spatial GIS based model using landscape characteristics they could produce a regional-scale map of the distributions of GDEs. However, it is not known whether this approach could be applied to Class III GDEs (those reliant on sub-surface access to groundwater).

In arid and semi-arid regions, plant density is often correlated with water availability. When groundwater is available to vegetation, plant density tends to be larger than adjacent areas where groundwater is unavailable. Lv et al. (2012) used remotely sensed images of a vegetation index (the Normalised Difference 
Fig. 13.4 The relationship between NDVI and depth-togroundwater for the Hailiutu River catchment in northern China (Redrawn from Lv et al. 2012)

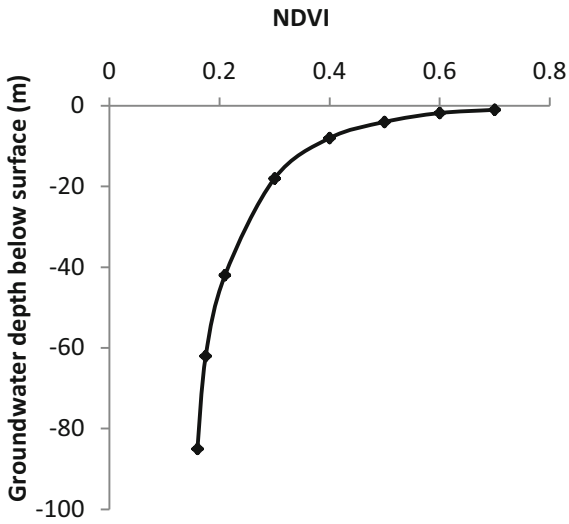

Vegetation Index; NDVI) to assess changes in NDVI as a function of depth-togroundwater in northern China. A $25 \mathrm{~m}$ resolution digital elevation model and groundwater bore data were used to generate a contour map of groundwater depths across the $2600 \mathrm{~km}^{2}$ catchment. Approximately 29,000 pixels of $300 \mathrm{~m}$ resolution of NDVI data were then used and the following relationship determined (Fig. 13.4):

This study demonstrated that the largest NDVI, a reliable measure of vegetation cover, occurred at the shallowest depths of groundwater and that cover declines curvilinearly with increasing depth-to-groundwater. They further analysed NDVI data and identified five land classes, including water bodies and bare earth as one land class, having a zero vegetation cover; and farmland and riparian zones as another class having the largest NDVI. The remaining three classes had intermediate values of NDVI. They then showed that the vegetated classes exhibited different responses to depth-to-groundwater. A cut-off of approximately $10 \mathrm{~m}$ depth-togroundwater was apparent; when the water table was lower than $10 \mathrm{~m}$, vegetation cover was insensitive to further increase in groundwater depth.

A similar method was applied by Jin et al. (2011) for the Ejina area in NW China. Despite much of the region being within the Gobi desert, with approximately $40 \mathrm{~mm}$ annual rainfall, an oasis located in the northern part of Ejina supports extensive agricultural and native vegetation. The NDVI was used by Jin and co-workers, along with 13 groundwater bores, from which relationships between NDVI and groundwater depth for three vegetation classes (grassland, woodland and scrubland) were established. Surprisingly, maximum NDVI were not observed at the shallowest groundwater sites for any vegetation class but at intermediate $(2.5-$ $3.5 \mathrm{~m}$ ) depths. A cut-off of $4.4 \mathrm{~m}$ depth-to-groundwater was observed such that vegetation was absent in regions where groundwater depth exceeded $5.5 \mathrm{~m}$.

Dresel et al. (2010) used geological, hydrogeological and ecological data to define regions having common physical and climatic profiles and which therefore should have similar RS signals. MODIS eVI and Landsat NDVI data were used and aridity thresholds (calculated as the Thornthwaite index) for individual regions developed based on a correlation analysis of Landsat summer NDVI images and 
MODIS eVI. Both of these are surrogate measures of productivity, with eVI generally performing better than NDVI (Campos et al. 2013).

Three methodologies were applied by Dresel et al. (2010). In the first, the MODIS eVI images identified pixels with a consistent photosynthetic activity throughout the year and pixels having variation across the year that was less than one standard deviation of the mean were deemed to show consistent productivity all year. For the second method, Landsat NDVI images were used to identify areas with contrasting photosynthetic activity for a wet year and a dry year. In the third method, an unsupervised classification of Landsat spectral data was used to identify spectral signatures of pixels that were deemed to be highly likely to use groundwater using expert local knowledge and then find other pixels with similar spectral signatures. Species specific differences in spectral signatures have been identified previously (Nagler et al. 2004). By combining all three methods within a GIS and finding pixels with a consistent productivity all year plus a high contrast between other local pixels plus a similar spectral signature to known GDEs, it was possible to identify all pixels across a catchment that had a very high probability of being a GDE. Ground truthing was then required.

An alternate approach to mapping the location of GDEs involves mapping of discharge zones, especially discharge through transpiration of vegetation and discharge to the ground surface. Discharge of groundwater to the surface (to swamps, wetlands and rivers) or through transpiration exerts a profound effect on the ecology of those systems utilising groundwater. To define the spatial extent of discharge across a landscape requires a multi-disciplinary approach that incorporates knowledge of geology, hydrology, ecology and climate (Tweed et al. 2007). Leblanc et al. (2003a, b) for example, used thermal, Landsat optical and MODIS NDVI data coupled to digital elevation models and depth-to-groundwater data to locate discharge areas in a large semi-arid basin in the Lake Chad basin in Africa. Tweed et al. (2007) examined discharge (and recharge) of the Glenelg-Hopkins catchment of southeast Australia. Discharge occurred through direct evaporation of the water table, with a likely limit of $5 \mathrm{~m}$ depth from which evaporation could occur; transpiration by vegetation from regions overlying a shallow unconfined aquifer and discharge to the ground surface to localised depression, break-of-slope localities and to wetlands, rivers and the ocean. The methodology they employed is summarised thus (from Tweed et al. 2007, Fig. 13.5).

Key indicators of groundwater discharge used in this study include:

1. Low variability of vegetation activity across wet and dry periods (seasons or years) using the NDVI as a measure of vegetation photosynthetic activity.

2. Topographic depressions and breaks of slope across the catchment, derived from a digital elevation model for the catchment to identify potential locations for surface discharge. A topographic wetness index $(w)$ was calculated from: $w=\ln$ $(1 / \tan \beta)$ where $\beta$ is the gradient of the slope of the land surface. Identification of concave slopes by identifying negative second-derivatives of slopes was used to identify areas where potential zones of saturation (arising from groundwater discharge) may occur across the landscape. 
Fig. 13.5 A schematic of the methodology used by Tweed et al. (2007) in the use of RS and GIS to identify the location of GDEs in a landscape

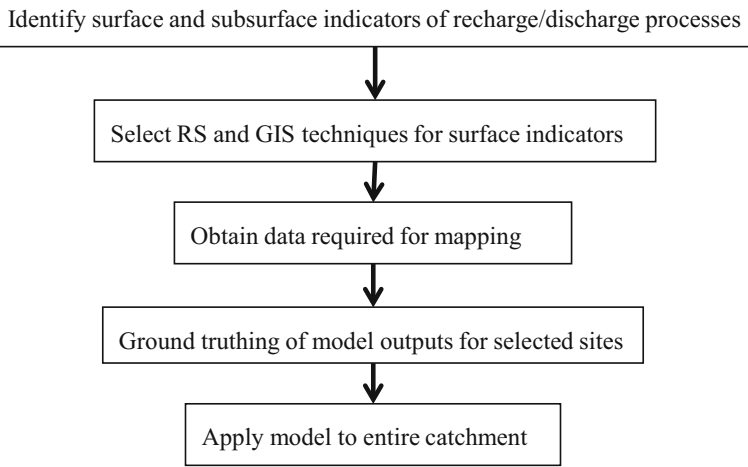

3. Groundwater depth data were used to produce a groundwater flow and these were combined with the digital elevation map to produce a depth-togroundwater map.

From this approach a detailed map of potential discharge zones across the entire $11,000+\mathrm{km}^{2}$ catchment was produced that far exceeded the ability if only the limited bore data had been used. A map of the standard deviation of the NDVI was able to identify locations where groundwater was supporting vegetation activity and thus identify GDEs across the catchment. A potential limitation to this method was that it tended to be most accurate in drier parts of the catchment where rainfall is more likely to limit vegetation activity. It was also found that identification of topographic depressions was a more reliable indicator for groundwater discharge than identification of break-of-slope.

\subsubsection{RS Derived Estimates of Water Fluxes}

The energy balance equation for land surfaces can be written thus: $L E+H=R_{n}-G$, where $L E$ is latent energy flux ( $=E T), H$ is sensible heat flux, $R_{n}$ is net radiation and $G$ is soil heat flux. Differences in temperature between boundary air temperature and canopy temperature can be used to estimate sensible heat flux. Assuming over a 24 h cycle $G=0$, and $R_{n}$ is either measured or derived from remote sensing data, then $L E$ (that is, ET) is calculated by difference. Li and Lyons (1999) used three models based on surface temperatures to estimate ET. The first model only used differences in surface and air temperature to calculate ET, the second model required NDVI data and surface temperature. This model requires the four extreme values of surface temperature and NDVI to be present within the area of study (i.e. patches of dry bare soils, wet bare soil, wet fully vegetated patches and dry (water stressed) fully vegetated surfaces). This makes its application problematic. The third method simply used the Priestley-Taylor equation (see Li and Lyons $1999)$ to estimate potential ET $\left(\mathrm{E}_{\mathrm{p}}\right)$.

Two of the key functional attributes of terrestrial ecosystems are the rates of water-use (either transpiration or evapotranspiration) and the rates of carbon 
fixation. Fluxes of transpired water and carbon uptake are coupled through the action of stomata, through which both gases must flow. It is because of the tight coupling of water and carbon fluxes that vegetation indices such as NDVI or eVI, which are good proxies of productivity and hence carbon flux, can be successfully applied in looking for GDEs, where it is an increase in water supply that drives their structural and functional differences (compared to adjacent no-GDEs).

\subsubsection{GDE Mapping and Database Challenges}

Information management constitutes a serious challenge for understanding and managing GDEs. Accurately georeferencing and archiving data on the distribution and ecohydrology of springs and other GDEs first involves developing a suitable database framework (Springs Stewardship Institute 2012). Some or many of the above methods for determining GDE distribution allows development of a geographic information system georeferenced map of springs within landscapes. However, a common problem in such mapping efforts is resolution of duplication error. We have repeatedly found that: (a) no single source of information (usually GIS layers or survey reports) provides a complete list of springs or other GDEs within a large landscape; (b) that each information source contains unique springs not found elsewhere; and (c) that the same GDEs may be mapped in multiple places with different names. Stevens and Ledbetter (2012) used 10 sources of information to identify 150 springs on the North Kaibab Forest District of northern Arizona, $50 \%$ more springs than had been documented by the managing agency, and field surveys increased the number of known springs in that landscape to more than 200. Development of an adequate map and database on the springs of large landscapes provides an essential tool for monitoring, modelling and further research on the status of the underlying aquifers.

\subsection{Estimating Rates of Groundwater Use by Class III GDEs}

Estimating groundwater needed to maintain GDE function is an essential step to the sustainable management of both GDEs and groundwater resources. However, it poses many methodological impediments, including:

1. Up-scaling from tree-scale measurements of tree water-use;

2. Partitioning total vegetation water-use into rain and groundwater sources;

3. Understanding seasonal/life-cycle variations in the rates of groundwater use;

4. Understanding the influence of climate at inter-annual time-scales on rates of tree water-use and the partitioning of water-use into rain and groundwater sources.

Moreover, what is required for the establishment and persistence of GDE function is often not well characterized; therefore the emphasis has been on 
Table 13.1 Three methods to estimate rates of groundwater discharge through vegetation in data poor areas, summarised from Leaney et al. (2011)

\begin{tabular}{l|l|l}
\hline Model & Input data & Method \\
\hline $\begin{array}{l}\text { Groundwater } \\
\text { risk model }\end{array}$ & $\begin{array}{l}\text { Climatic characterisation (rainfall, } \\
\text { evaporation), depth-to- } \\
\text { groundwater, soil profile } \\
\text { characterisation (depth, texture, } \\
\text { moisture holding), groundwater } \\
\text { salinity }\end{array}$ & $\begin{array}{l}\text { Uses a simple water balance } \\
\text { approach to estimate the probability } \\
\text { of groundwater use and estimate } \\
\text { groundwater discharge }\end{array}$ \\
\hline $\begin{array}{l}\text { Ecological } \\
\text { optimality } \\
\text { model }\end{array}$ & $\begin{array}{l}\text { Climatic characterisation (rainfall, } \\
\text { evaporation), long term average } \\
\text { Leaf Area Index (LAI) }\end{array}$ & $\begin{array}{l}\text { Estimates groundwater discharge } \\
\text { based on the difference between LAI } \\
\text { of GDE and theoretical LAI for a } \\
\left.\text { given climate wetness index (P/E } E_{0}\right)\end{array}$ \\
\hline $\begin{array}{l}\text { Groundwater } \\
\text { discharge- } \\
\text { salinity function }\end{array}$ & Groundwater salinity & $\begin{array}{l}\text { Estimates groundwater discharge } \\
\text { based on empirical relationship } \\
\text { between groundwater discharge and } \\
\text { groundwater salinity }\end{array}$ \\
\hline
\end{tabular}

measuring water use in existing GDEs and using this characterization as a basis for baseline conditions. A range of tools are available to estimate groundwater use by Class III GDEs. These are now briefly discussed.

\subsubsection{A Spreadsheet Tool}

Because of the paucity of data on points (1)-(4) above, Leaney and co-workers developed a novel, simple, but useful first-order method to estimate groundwater use of vegetation using a simple excel spreadsheet tool (Leaney et al. 2011). The excel spreadsheet includes three methods to estimate rates of groundwater discharge through vegetation:

(a) a groundwater risk model;

(b) an ecological optimality model; and

(c) a groundwater discharge salinity function.

These are summarised in Table 13.1.

The groundwater risk model is a simple water balance model that uses historical monthly rainfall and monthly evaporation data for any site. The soil profile is defined by the user and soil texture is used to estimate soil moisture characteristics for each layer. Groundwater discharge through vegetation is deemed to occur whenever evapotranspiration (ET) exceeds rainfall plus the soil water stores. 


\subsubsection{Sub-daily Fluctuation in Groundwater Depth}

In addition to being used to identify the location/presence of a GDE in a landscape, the White method (White 1932) described in Sect. 13.3.2 for analysing sub-daily changes in depth-to-groundwater can be used to quantify rates of groundwater use. The volume of water transpired is calculated from the change in volume of water in the aquifer that would account for the observed changes in the depth of the water table on an hourly or daily basis, assuming the specific yield of the aquifer is known with sufficient accuracy and confidence. Butler et al. (2007) examined the controls of variation in rates of groundwater use across several riparian sites in the High Plains region of the USA. They found that the principle drivers of vegetation water use were meteorological, vegetation attributes and the specific yield of the aquifer. Their estimates of groundwater use $\left(3-5 \mathrm{~mm} \mathrm{~d}^{-1}\right)$ agreed well with estimates derived from sapflow measurements of tree water use. For a detailed assessment of the technical problems inherent in application of the White method, the reader is referred to Loheide et al. (2005). Further examples of estimating rates of groundwater use using the White method can be found in Lautz (2008), Martinet et al. (2009) and Gribovszki et al. (2008).

\subsubsection{Using Remote Sensing to Estimate Groundwater Use}

Methods for remotely sensed estimates of groundwater discharge are being developed. It is important to quantify the water balance of arid and semi-arid groundwater basins to define safe yields for those resources. Obtaining accurate and spatially distributed estimates of discharge through vegetation is problematic, expensive and time consuming using field techniques. Consequently, Groeneveld and Baugh (2007) derived a new formulation of the standard NDVI which stretches the NDVI distribution for vegetation from zero to one. This new NDVI (NDVI*) can be calibrated to quantify actual rates of evapotranspiration $\left(E T_{a}\right)$ and the calibration only requires standard weather data from which to calculate $\left(E_{o}\right)$ (the grass reference ET calculated using the Penman-Monteith equation, as described in the FAO-56 method (Allen et al. 1998). The $N D V I^{*}$ is functionally equivalent to the crop coefficient $\left(K_{c}\right)$ commonly used in micrometeorology. This methodology is especially applicable to vegetated arid and semi-arid sites with a shallow water table where rainfall is low, often erratic but water supply to roots is relatively constant. Consequently $E T$ closely tracks $E T_{o}$, which varies as a function of solar radiation, wind speed and vapour pressure deficit.

Groeneveld et al. (2007) applied the $N D V I^{*}$ methodology to three disparate arid sites in the USA where annual $E T_{a}$ values were available through use of Bowen ratio or eddy covariance equipment. A linear correlation $\left(\mathrm{R}^{2}=0.94\right)$ between measured annual $E T_{a}$ and mid-summer $N D V I^{*}$ was obtained across the pooled, three-site data, despite very different vegetation composition and structure across the three sites. 
Deducting the contribution of annual rainfall to annual $E T_{a}$ yields the amount of groundwater that is transpired by the vegetation $\left(E T_{g w}\right)$. Thus, $E T_{g w}=\left(E T_{o}-\right.$ rainfall)NDVI* Across sites and across years, the average error in $E T_{g w}$ was estimated to be about $12 \%$, which in the absence of field assessments is a very valuable estimate of groundwater use.

Groeneveld (2008) applied the methodology of Groeneveld et al. (2007), using mid-summer NDVI data to estimate annual total ET of alkali scrub vegetation in Colorado. An estimate of annual groundwater use was then estimated as the difference between annual rainfall and annual ET for each year. On-site estimates of groundwater use were larger than those estimated using NDVI data and $E T_{o}$ because the remote sensing method does not include surface evaporation of groundwater. Annual $E T_{g w}{ }^{*}$ were compared to measurements made by Cooper et al. (2006) at the same site agreed to within $20 \%$. Similarly, as noted earlier in the discussion of RS methods to find ET, Scott et al. (2008) developed a numeric relationship for $E T_{a}$ and concluded that the difference between $E T_{a}$ and annual rainfall was groundwater use.

\subsubsection{Using Stable Isotopes to Estimate Rates of Groundwater Use}

Stable isotopes have been used extensively to provide estimates of the proportion of total vegetation water use that is derived from groundwater (Feikema et al. 2010; Kray et al. 2012; Máguas et al. 2011; McLendon et al. 2008; Querejeta et al. 2007). Thus, an independent estimate of rates of water use are required in addition to analyses of the stable isotope composition of soil water, groundwater and xylem water. Methods to estimate rates of vegetation water use include eddy covariance (Eamus et al. 2013), measurement of rates of sapflow (Zeppel et al. 2008) and remotely sensed estimates (Nagler et al. 2009). When only a single isotope is analysed $\left({ }^{2} \mathrm{H}\right.$ or $\left.{ }^{18} \mathrm{O}\right)$ a linear mixing model can distinguish between only two potential sources of water (groundwater and soil water). If both isotopes are used, spatial resolution is increased and one can distinguish between three sources of water, but only if the two isotopic compositions are independent of each other, which is often not the case. Interestingly, early work in 1996 established that the application of stable isotope analyses was found to be the most accurate method available in a comparative analysis of wetland groundwater inflows (Springs Stewardship Institute 2012).

Two generalities can be identified in the results of stable isotope studies of GDEs. First, as depth-to-groundwater increases, the proportion of total vegetation water-use that is derived from groundwater diminishes (O'Grady et al. 2006) although this can vary amongst different vegetation communities (McLendon et al. 2008). Second, the proportion of groundwater used by vegetation usually (McLendon et al. 2008) but not always (Kray et al. 2012) increases as time since last rain increases and soils dry out and thus seasonality of groundwater use may occur when rainfall is highly seasonal and groundwater availability is maintained throughout the dry season (O'Grady et al. 2006). 
Stable isotope composition varies as a function of depth (Fig. 13.3) and taking an average value to represent the entire rooting depth of the vegetation leads to errors. Even with two independent isotopes available for analyses, the relative contribution of only three sources can be determined. To overcome this limitation, Cook and O'Grady (2006) developed a simple model of water uptake whereby the relative uptake from different depths is determined by (1) the gradient in water potential between the soil and the canopy; (2) root distribution as a function of depth; and (3) a lumped hydraulic conductance parameter. Isotopic composition of water through the soil profile and of xylem water is then used to constrain root distributions (as opposed to measuring this destructively in situ). This model has several advantages over the more commonly used end-member (Phillips and Gregg 2003) analyses: (1) produces a more quantitative estimation of proportion of water extracted from different depths (including groundwater); (2) does not require distinct values of isotope composition for end-member analyses and therefore can deal with the more typical grading of isotope composition observed through the soil profile; and (3) is based on simple ecophysiological principles. Sapflow sensors were used to measure rates of tree water use across four species growing in a tropical remnant native woodland and this was up-scaled using plot basal area. Cook and O'Grady (2006) demonstrated that two species were sourcing 7-15\% of its transpirational water from the water table, a third species was accessing $100 \%$ of its water from the water table and a fourth species was accessing between $53 \%$ and $77 \%$ of its water from the water table - further confirmation of niche separation of patterns of water uptake for co-occurring species.

\subsection{Threats to GDEs}

Human activities threaten GDEs by disturbing habitats, depleting groundwater reserves, altering the groundwater regime at a site beyond the natural bounds of variation previously experienced at that site, and degrading groundwater quality. Globally, GDEs are and will continue to be threatened by groundwater depletion due to increasing water demands from growing populations and increased industrial demand (Danielopol et al. 2003). Wada et al. (2010) estimated that global groundwater depletion (i.e. groundwater abstraction in excess of recharge) in sub-humid to arid areas was approximately $280 \mathrm{~km}^{3} \mathrm{yr}^{-1}$ in 2000 , doubled from 1960. Increasing water demands was projected to greatly outweigh climate change in defining global water resource to 2025 (Vörösmarty et al. 2000). Locally, human activities have impacted GDE habitats through vegetation clearing, filling or draining of wetlands and alteration of surface water courses. Regionally, major anthropogenic threats to GDEs include

- alteration of surface water regime and quality through river regulation and landuse change; 


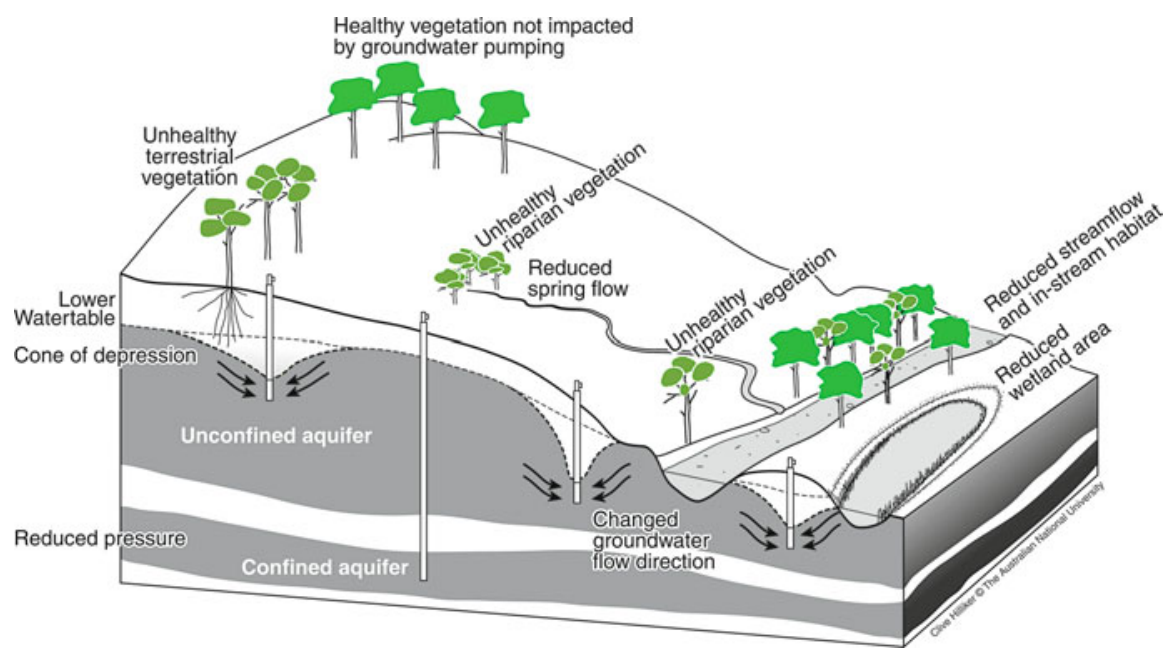

Fig. 13.6 Diagram showing the potential impacts of groundwater pumping on GDEs

- alteration of groundwater regime and quality as a result of agricultural practices, urban and industrial development, mining activities and plantation forestry (Fig. 13.1).

For GDEs that rely on both surface and groundwater sources, surface water regime (including flooding) and quality are considered the most important factor threatening GDEs (Eamus et al. 2006). Evidences of ecosystem change due to flow alteration and surface water quality decline have been reviewed elsewhere (Nilsson et al. 2005; DeFries et al. 2004). This section focuses on groundwater regime and groundwater quality.

\subsubsection{Anthropogenic Threats to Groundwater Regime}

Groundwater extraction is one of the major threats that alters groundwater regime. Groundwater has been extracted to support agricultural activities (especially irrigation), to satisfy residential water-use and to support urban and industrial development. In these cases, groundwater is often extracted through pumping wells in confined or unconfined aquifers. Excessive groundwater pumping in a confined aquifer will depressurise the entire confined aquifer and reduce groundwater discharge to springs (Weber and Perry 2006) (Fig. 13.6). The impact is at a regional scale. In contrast, impact of groundwater pumping from an unconfined aquifer is more localised. In unconfined aquifers, when extraction is faster than recharge, groundwater depth increases forming a "cone of depression" around the well that can extend for many hundreds of meters from the well (Fig. 13.6). In addition, groundwater flow direction can be changed because of the generation of new 
hydraulic gradients: groundwater may no longer flow into the local stream, and some water may be drawn from the stream to the well, thereby reducing stream flow. The time lag between extraction and a reduction in discharge to a stream vary from a few hours to many centuries, depending on extraction locations (relative to the stream), extraction volume and groundwater flux (Evans 2007).

Increased depth-to-groundwater and the disappearance of springs have been reported around the world and are associated with excessive groundwater pumping for agricultural and urban development, mining activities and plantation forestry (Fig. 13.1). Depth-to-groundwater has increased by $4-17 \mathrm{~m}$ in an irrigation region of northwest China, forming several cones of depression covering about $1000 \mathrm{~km}^{2}$ (Wang et al. 2003). Similarly, Burri and Petitta (2004) observed progressive disappearance of numerous springs in the Fucino Plain, Italy, due to increased agricultural water-use for water-intensive horticultural crops and second harvest practices. In some areas of extensive urban development, groundwater depletion has occurred at alarming rates. For example, in London the water table has dropped more than $70 \mathrm{~m}$ below the surface (Elliot et al. 1999); in Bangkok, the water table has dropped by $25 \mathrm{~m}$ since 1958; in Tamil Nadu, India, a $30 \mathrm{~m}$ decline in 15 years has occurred (Danielopol et al. 2003). Muñoz-Reinoso (2001) reported that the decline of water table in Doñana, Spain was primarily due to pumping for urban water supply of a tourist resort and secondarily due to the transpiration of large pine plantations. Mine dewatering (removal of water by pumping or evaporation) can have large impacts on aquifer and cave system locally, and springs close to mine sites. Cluster of mining operations can impact depth-to-groundwater at regional scales due to their cumulative effects (Clifton and Evans 2001).

In addition to groundwater extraction and mine dewatering activities, in-channel gravel or sand mining can cause the incision of a riverbed which lowers the alluvial water tables (Kondolf 1994). Scott et al. (1999) reported water table declines of more than $1 \mathrm{~m}$ at sites affected by gravel mining (compared to no significant decline at control sites). Sustained lowering of the water table greater than $1 \mathrm{~m}$ has led to significant declines in Populus growth and $88 \%$ mortality over a 3-year period (Scott et al. 1999). Water-logging, typically caused by forest clearing and poorly managed irrigation in agricultural lands can result in a rise in the water table, and associated impacts through impaired root function because of the development of anoxic conditions within the root zone (Pimentel et al. 1997).

\subsubsection{Anthropogenic Threats to Groundwater Quality}

Reports of groundwater contamination caused by human activities are abundant. Nitrate leaching from agricultural lands to shallow groundwater has been reported in many regions around the world (Andrade and Stigter 2009). Elevated nitrate levels in groundwater can be sourced from nitrogen fertilizers and manure, oxidation of organically bound nitrogen in soils, cattle feed lots, septic tanks and sewage discharge. Severity of contamination is modified by other factors such as lithology, 
dissolved oxygen levels and land-use. Andrade and Stigter (2009) reported that rice fields on fine-grained alluvium generally have low dissolved oxygen and minimal nitrate concentrations in groundwater due to denitrification. In contrast, areas with vegetable crops coupled with coarse grain lithology and high hydraulic conductivity have higher concentrations of nitrate in shallow groundwater. Discharge of nitrate enriched groundwater can alter nitrogen concentrations in the receiving water and hence increase the risk of eutrophication and algal blooms.

Pesticide contamination can be a problem for shallow groundwater. In the US, more than half of the wells in agricultural and urban areas contain one or more pesticide compounds (Gilliom et al. 2006). Using poor quality pesticides with low degradation rates, incorrect application of pesticides and inappropriate disposal methods can all lead to groundwater being contaminated by pesticides, among which herbicides are the most frequently detected in groundwater (Andrade and Stigter 2009).

Urban development can impair groundwater quality, thereby damaging urban ecosystems. Examples include leakage from septic tanks, underground fuel tanks, landfills, and use of fertilisers and pesticides for gardens and recreation areas. Animal rearing, horticultural activity, solid waste dumping, pit latrine construction and stormwater/sewage disposal have led to increased localised microbial and organic contamination of shallow groundwater (Kulabako et al. 2007; Massone et al. 1998). Foppen (2002) reported increased concentrations of almost all major cations and anions and acidification of groundwater at Sana'a, Yemen, due to continuous infiltration of wastewater into the aquifers via cesspits. More recently, urban groundwater in cities of Germany has been shown to be polluted with xenobiotics such as pharmaceuticals, personal care products (collectively known as PPCPs) and endocrine-active substances (Schirmer et al. 2011). However, their potential long-term effects on ecosystems and humans remain largely unknown.

Mining can contaminate groundwater during mining operation (e.g. leakage from tailings dams and crushed rock waste dumps, which can cover hundreds of hectares at a mine site), as well as the recovering phases after mine sites are abandoned (Younger and Wolkersdorfer 2004; Gao et al. 2011). Dewatering disturbs groundwater stratification, thereby altering the environment required by cave or aquifer ecosystems and associated stygofauna. Cidu et al. (2001) reported that mine closure and associated cessation of groundwater pumping and mine flooding may pose a contamination risk to shallow aquifers due to the rise of deep saline groundwater. Progressive mine flooding also causes groundwater contamination via weathering of ore minerals and remobilization of metals in the mine waste (Razowska 2001).

In summary, groundwater regime and quality are threatened by many human activities, including agricultural practices, urban and industrial development, mining activities and plantation forestry. These threats can have profound impact on GDEs in the short and long term, at local and regional scales. The impacts of groundwater abstraction on GDEs and their restoration are discussed below using two case studies. 
Shoot growth rate declines; root growth stimulated

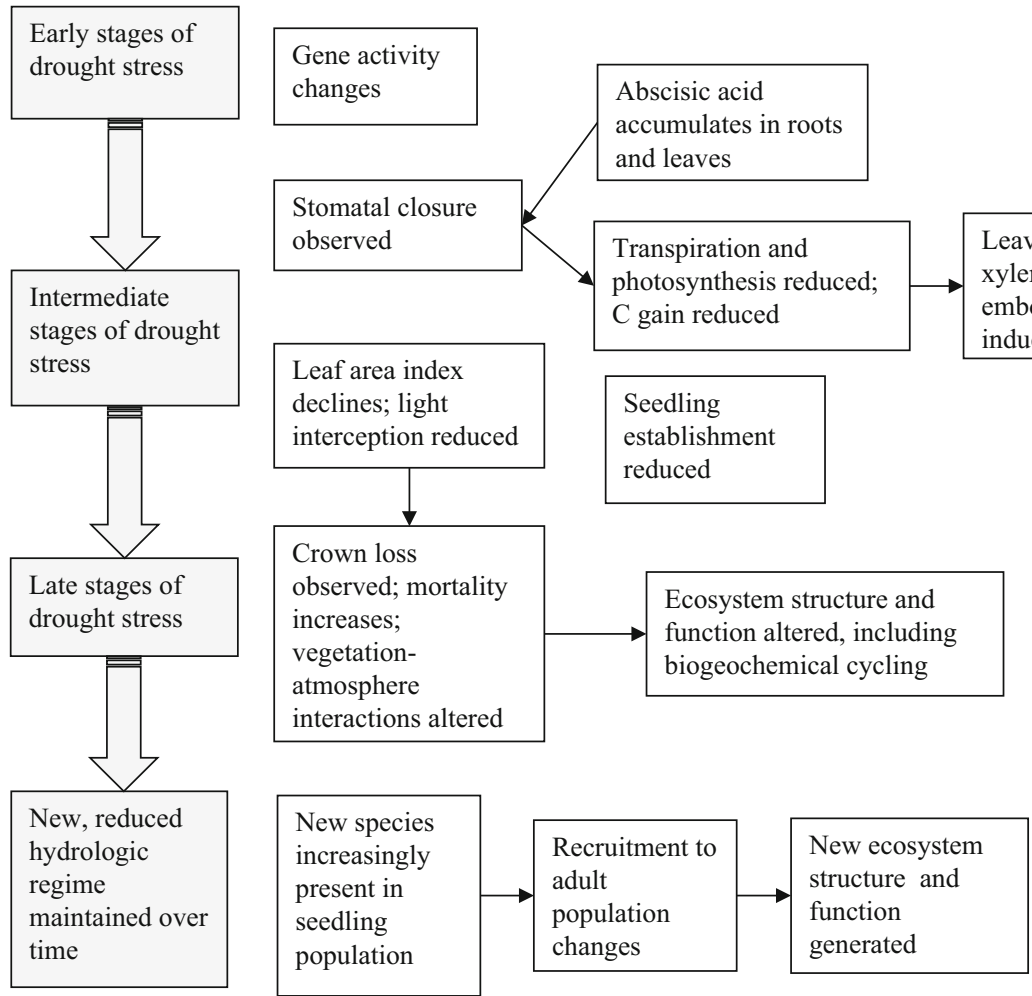

Fig. 13.7 Schematic outline of some of the changes in plant physiology, ecophysiology and ecology associated with short-, medium- and long-term changes in water availability

\subsubsection{Case Study 1: Terrestrial Vegetation}

The impacts of groundwater abstraction on woodlands has been documented for the Gnangara Mound, a shallow unconfined aquifer of the Swan Coastal Plain in Western Australia (Canham et al. 2009, 2012; Groom et al. 2000; Stock et al. 2012). Increased depth-to-groundwater is the result of a long-term decline in annual rainfall across the region, increased abstraction for human use and increased discharge (reduced recharge) arising from the development of a plantation industry in the region. A range of changes in plant physiology, ecophysiology and ecology are found associated with short-, medium- and long-term changes in water availability (Fig. 13.7).

In 1985 increased rates of summer abstraction in this Mediterranean climate resulted in increased and widespread mortality (up to $80 \%$ mortality close to the abstraction bores) of the native Banksia woodland. To determine longer-term 
floristic changes arising from groundwater abstraction, a series of transect studies were initiated in 1988. A $2.2 \mathrm{~m}$ increase in depth-to-groundwater, coupled to higher-than-normal summer temperatures resulted in a $20-80 \%$ adult mortality of overstory species and up to $64 \%$ mortality in the understory species, 2 years after the start of groundwater pumping (Groom et al. 2000). Control sites, not impacted by groundwater pumping, did not display increased mortality.

Because of the large inter-species differences in rates of mortality, a further study examined the vulnerability of different species to reduced water availability (Canham et al. 2009; Froend and Drake 2006). Using xylem embolism vulnerability curves as an indicator of sensitivity to water stress, Froend and Drake (2006) compared three Bankisa and one Melaleuca species. They found that xylem vulnerability reflected the broad ecohydrological distribution of the species across the topographic gradient present at the site and they were able to identify a threshold leaf water potential below which increased mortality was likely.

Similarly, Canham et al. (2009) examined Huber values (the ratio of sapwood to leaf area), leaf-specific hydraulic conductivity $\left(k_{l}\right)$ and xylem vulnerability of two obligate phreatophytes and two facultative phreatophytes. At sites were water availability was high (no increase in depth-to-groundwater) there were no interspecific differences in vulnerability to water stress. However, in a comparison of the upper and lower slopes (corresponding to larger and smaller depth-to-groundwater respectively) the two facultative phreatophytes (but not the obligate phreatophytes) were more resistant to xylem embolism at the upper slope than the lower slope, whilst one of the obligate phreatophytes did not alter its sensitivity (Canham et al. 2009).

In addition to differences in sensitivity of above-ground tissues to changes in water availability, it is likely that differences in the responses of root to changes in depth-to-groundwater contribute to the impact of changes in depth-to-groundwater on vegetation in GDEs. In a comparative study on two Banksia tree species, Canham et al. (2012) observed that root growth at sites with shallow depth-togroundwater was in synchrony with above-ground growth patterns. This was in contrast to patterns observed at depth, where root growth occurred all year and was independent of aerial climate. As depth-to-groundwater increased during the summer in this winter rainfall site, roots grew increasingly deeper, following the capillary fringe. As recharge occurred in the winter and depth-to-groundwater declined, anoxia resulted in root death at depth. These authors concluded that the ability to rapidly increase root depth during the summer is a critical attribute of phreatophytes occupying sites with seasonally dynamic depth-to-groundwater.

Long-term ( $>2$ years) studies of the influence of changes in depth-to-groundwater are relatively rare, despite the importance of such studies to the development of ecosystem response trajectories for the impact of groundwater abstraction. Froend and Sommer (2010) examined a rare, 40 year duration, vegetation survey data-set for the Gnangarra Mound in Western Australia. Although the long-term (1976-2008) average rainfall in $850 \mathrm{~mm}$, this has been declining for the past 40 years. Currently the annual average is about $730 \mathrm{~mm}$. This, along with increased groundwater abstraction, has resulted in increases in the depth-to-groundwater over 
the past 50 years of about $1 \mathrm{~m}$. Seasonally, depth-to-groundwater fluctuates about $0.5-3 \mathrm{~m}$, with a maximum depth occurring at the end of the summer. Two transects were used - a "control" transect where gradual increases in depth-to-groundwater $\left(9 \mathrm{~cm} \mathrm{y}^{-1}\right)$ have occurred as a result of the decline in annual rainfall over the past several decades; and an "experimental" transect where large rates of increase in depth-to-groundwater $\left(50 \mathrm{~cm} \mathrm{y}^{-1}\right)$ because of declining rainfall and extensive abstraction of groundwater have occurred. Three vegetation communities were identified with principal coordinate analyses and these were clearly associated with down-slope, mid-slope and upper-slope positions, corresponding to shallow, intermediate and deep depth-to-groundwater respectively. Species known to have a high dependency on consistent water supplies (mesic species) were dominant at the down-slope site whilst xeric species dominated the upper-slope sites.

On the control transect (slow rates of increase in depth-to-groundwater), the hypothesis that groundwater water abstraction would result in a replacement of the mesic by the xeric species was not supported. Most of the compositional and structural attributes of the three communities were unchanged. The principle community-scale response was a change in the abundance of mesic and xeric species rather than a complete replacement of one species for another. In contrast to the results of Shafroth et al. (2000), mesic species growing on sites with shallow groundwater were not more sensitive to increases in depth-to-groundwater than xeric species.

On the "experimental" transect where the increase in depth-to-groundwater was much faster $\left(50 \mathrm{~cm} \mathrm{y}^{-1}\right)$ changes in composition were far more pronounced and mass mortality observed across all classes (mesic to xeric) species. This result emphasises the importance of the rate of increase in depth-to-groundwater in determining the response of species and communities.

\subsubsection{Case Study 2: Restoration of Springs}

A systematic review of the literature of the restoration of arid-land springs was conducted by Stacey et al. (2011) to determine how successful projects were in restoring hydrology, geomorphology, and biological assemblage composition and structure in relation to those at natural springs with minimal anthropogenic disturbances. Unfortunately, the great inconsistency in the rationale for and in the implementation, monitoring, and reporting of springs restoration efforts globally made it impossible to conduct meta-statistical analyses of the quality of restoration. Stacey et al. (2011) recommended standardised ecosystem condition and restoration assessment protocols are needed to more clearly understand the success of projects. Because of the inability to report on a global summary of the success of restoration and management, we provide a case study by specific spheres of discharge to provide some lessons learned from restoration and management actions.

Hoxworth Springs is a rheochrene spring on the Mogollon Rim of the southwestern Colorado Plateau (Godwin 2004). This system is typical in both the morphology and degradation of many stream channels associated with rheochrene 
springs of the Southwestern USA. Causes for the channel down-cutting of the system are attributed to anthropogenic modification of the channel with the installation of a series of low-head dams and grazing of domestic animals and introduced, non-native wildlife in the channel and the drainage basin. In cooperation with land managers, channel restoration was completed to return the function and structure of the system. Restoration included stream channel morphologic reconstruction and hydrologic and vegetative monitoring. The channel was significantly incised and the sinuosity decreased resulting in greater flow velocities, steep channel banks, and flood flows which couldn't dissipate over the flood plain.

The restoration of Hoxworth Springs included reshaping of the channel based on morphologic patterns observed in abandoned reference sections of the channel on the flood plain surface and with similar runoff dominated rheocrene spring channels in the region (Griffiths et al. 2008). Re-vegetation was performed to stabilize the restored channel banks and large exclosures were constructed to manage grazing along the channel. A three-dimensional groundwater flow model was created to help interpret and predict effects of the restoration effort on perennial stream discharge, effectiveness of the restoration, and system response to climatic extremes. The model demonstrated that the length of perennial flow in the channel was dependent on the recent climate conditions. The use of a groundwater model to evaluate restoration efforts allows the user to modify recharge conditions based upon climatic or hydrologic perturbations and estimate impacts to the length of perennial flow and water availability to the riparian ecosystem.

\subsection{Concluding Remarks}

We now have, for the first time, a range of tools that cover the full temporal and spatial scales across which ecology moves (seconds-to-decades; from leaf-to whole-of-catchment). Measurements of stomatal or canopy conductance, sapflow, canopy temperature, leaf area index and rates of evapotranspiration and productivity can be made using ecophysiological techniques and remote sensing technologies. These data can be used in simple, moderate and complex models of ecosystem structure and function to identify the presence, areal extent and health of GDEs. What remains to be done? The three largest knowledge gaps are, in our opinion, (1) definition of the response function of ecosystems to changes in groundwater availability or groundwater quality; (2) determination of the threshold for GDEs beyond which unacceptable changes in GDE structure and function occur; and (3) a mechanistic understanding (and hence predictive capacity) of the interaction of future climate variability on GDEs.

Open Access This chapter is distributed under the terms of the Creative Commons AttributionNoncommercial 2.5 License (http://creativecommons.org/licenses/by-nc/2.5/) which permits any noncommercial use, distribution, and reproduction in any medium, provided the original author(s) and source are credited. 
The images or other third party material in this chapter are included in the work's Creative Commons license, unless indicated otherwise in the credit line; if such material is not included in the work's Creative Commons license and the respective action is not permitted by statutory regulation, users will need to obtain permission from the license holder to duplicate, adapt or reproduce the material.

\section{References}

Allen RG, Pereira LS, Raes D, Smith M (1998) Crop evapotranspiration-guidelines for computing crop water requirements. FAO Irrigation and drainage paper 56, FAO, Rome 300:6541

Andrade AIASS, Stigter TY (2009) Multi-method assessment of nitrate and pesticide contamination in shallow alluvial groundwater as a function of hydrogeological setting and land use. Agric Water Manag 96(12):1751-1765. doi:10.1016/j.agwat.2009.07.014

Blyth J, English V (1996) Endangered - tumulus springs. Landscope 11:47

Boulton A, Humphreys W, Eberhard S (2003) Imperilled subsurface waters in Australia: biodiversity, threatening processes and conservation. Aquat Ecosyst Health Manage 6(1):41-54

Burri E, Petitta M (2004) Agricultural changes affecting water availability: from abundance to scarcity (Fucino Plain, central Italy). Irrig Drain 53(3):287-299. doi:10.1002/Ird.119

Butler JJ, Kluitenberg GJ, Whittemore DO, Loheide SP, Jin W, Billinger MA, Zhan X (2007) A field investigation of phreatophyte-induced fluctuations in the water table. Water Resour Res 43(2):W02404. doi:10.1029/2005WR004627

Caldwell MM, Dawson TE, Richards JH (1998) Hydraulic lift: consequences of water efflux from the roots of plants. Oecologia 113(2):151-161

Campos GEP, Moran MS, Huete A, Zhang Y, Bresloff C, Huxman TE, Eamus D, Bosch DD, Buda AR, Gunter SA (2013) Ecosystem resilience despite large-scale altered hydroclimatic conditions. Nature 494(7437):349-352

Canham CA, Froend RH, Stock WD (2009) Water stress vulnerability of four Banksia species in contrasting ecohydrological habitats on the Gnangara Mound, Western Australia. Plant Cell Environ 32(1):64-72

Canham CA, Froend RH, Stock WD, Davies M (2012) Dynamics of phreatophyte root growth relative to a seasonally fluctuating water table in a Mediterranean-type environment. Oecologia 170(4):909-916

Cidu R, Biagini C, Fanfani L, La Ruffa G, Marras I (2001) Mine closure at Monteponi (Italy): effect of the cessation of dewatering on the quality of shallow groundwater. Appl Geochem 16 (5):489-502. doi:10.1016/S0883-2927(00)00046-9

Clifton CA, Evans R (2001) Environmental water requirements to maintain groundwater dependent ecosystems. Environmental flows initiative technical report number 2, Commonwealth of Australia, Canberra

Cook PG, O'Grady AP (2006) Determining soil and ground water use of vegetation from heat pulse, water potential and stable isotope data. Oecologia 148(1):97-107

Cook PG, Hatton TJ, Pidsley D, Herczeg AL, Held A, O’Grady A, Eamus D (1998) Water balance of a tropical woodland ecosystem, Northern Australia: a combination of micro-meteorological, soil physical and groundwater chemical approaches. J Hydrol 210(1-4):161-177. doi:10.1016/ S0022-1694(98)00181-4

Cook PG, Favreau G, Dighton JC, Tickell S (2003) Determining natural groundwater influx to a tropical river using radon, chlorofluorocarbons and ionic environmental tracers. J Hydrol 277 (1):74-88

Cooper DJ, Sanderson JS, Stannard DI, Groeneveld DP (2006) Effects of long-term water table drawdown on evapotranspiration and vegetation in an arid region phreatophyte community. J Hydrol 325(1):21-34 
Crossey LJ, Karlstrom KE (2012) Travertines and travertine springs in eastern Grand Canyon: what they tell us about groundwater, paleoclimate, and incision of Grand Canyon. Geol Soc Am Spec Pap 489:131-143

Danielopol DL, Griebler C, Gunatilaka A, Notenboom J (2003) Present state and future prospects for groundwater ecosystems. Environ Conserv 30(2):104-130. doi:10.1017/ S0376892903000109

DeFries RS, Asner GP, Houghton RA (2004) Ecosystems and land use change, vol 153. American Geophysical Union Geophysical Monograph Series, Washington, DC

Dresel P, Clark R, Cheng X, Reid M, Terry A, Fawcett J, Cochrane D (2010) Mapping terrestrial GDEs: method development and example output. Victoria Department of Primary Industries, Melbourne

Eamus D, Froend R, Loomes R, Hose G, Murray B (2006) A functional methodology for determining the groundwater regime needed to maintain the health of groundwater-dependent vegetation. Aust J Bot 54(2):97-114

Eamus D, Cleverly J, Boulain N, Grant N, Faux R, Villalobos-Vega R (2013) Carbon and water fluxes in an arid-zone Acacia savanna woodland: an analyses of seasonal patterns and responses to rainfall events. Agr Forest Meteorol. doi:10.1016/j.agrformet.2013.04.020

Elliot T, Andrews JN, Edmunds WM (1999) Hydrochemical trends, palaeorecharge and groundwater ages in the fissured Chalk aquifer of the London and Berkshire Basins, UK. Appl Geochem 14(3):333-363. doi:10.1016/S0883-2927(98)00060-2

Ernst CH, Lovich JE (2009) Turtles of the United States and Canada, 2nd edn. Smithsonian Institution Press, Washington/London

Evans R (2007) The effects of groundwater pumping on stream flow in Australia. Technical Report, Land \& Water Australia, Canberra

Feikema PM, Morris JD, Connell LD (2010) The water balance and water sources of a Eucalyptus plantation over shallow saline groundwater. Plant Soil 332(1-2):429-449

Foppen JWA (2002) Impact of high-strength wastewater infiltration on groundwater quality and drinking water supply: the case of Sana'a, Yemen. J Hydrol 263(1-4):198-216. doi:10.1016/ S0022-1694(02)00051-3

Froend R, Drake P (2006) Defining phreatophyte response to reduced water availability: preliminary investigations on the use of xylem cavitation vulnerability in Banksia woodland species. Aust J Bot 54(2): 173-179

Froend R, Sommer B (2010) Phreatophytic vegetation response to climatic and abstractioninduced groundwater drawdown: examples of long-term spatial and temporal variability in community response. Ecol Eng 36(9):1191-1200

Gao XB, Wang YX, Ma T, Hu QH, Xing XL, Yu Q (2011) Anthropogenic impact assessment of Niangziguan karst water. Proc Inst Civ Eng Water Manage 164(10):495-510, 10.1680/Wama. 1000070

Gilliom RJ, Barbash JE, Crawford CG, Hamilton PA, Martin JD, Nakagaki N, Nowell LH, Scott JC, Stackelberg PE, Thelin GP, Wolock DM (2006) Pesticides in the nation's streams and ground water, 1992-2001: the quality of our nation's waters. US Geological Survey, Reston, Virginia

Godwin TN (2004) Evaluation of streambed restoration and occurrence of Hoxworth Springs, Coconino County, Arizona. Northern Arizona University, Flagstaff

Gribovszki Z, Kalicz P, Szilágyi J, Kucsara M (2008) Riparian zone evapotranspiration estimation from diurnal groundwater level fluctuations. J Hydrol 349(1-2):6-17. doi:10.1016/j.jhydrol. 2007.10.049

Gribovszki Z, Szilágyi J, Kalicz P (2010) Diurnal fluctuations in shallow groundwater levels and streamflow rates and their interpretation - a review. J Hydrol 385(1):371-383

Griffiths RE, Anderson DE, Springer AE (2008) The morphology and hydrology of small springdominated channels. Geomorphology 102(3):511-521

Groeneveld DP (2008) Remotely-sensed groundwater evapotranspiration from alkali scrub affected by declining water table. J Hydrol 358(3):294-303 
Groeneveld DP, Baugh WM (2007) Correcting satellite data to detect vegetation signal for eco-hydrologic analyses. J Hydrol 344(1):135-145

Groeneveld DP, Baugh WM, Sanderson JS, Cooper DJ (2007) Annual groundwater evapotranspiration mapped from single satellite scenes. J Hydrol 344(1):146-156

Groom BPK, Froend RH, Mattiske EM (2000) Impact of groundwater abstraction on a Banksia woodland, Swan Coastal Plain, Western Australia. Ecol Manage Restor 1(2):117-124

Hancock P, Boulton A, Humphreys W (2005) Aquifers and hyporheic zones: towards an ecological understanding of groundwater. Hydrogeol J 13(1):98-111. doi:10.1007/s10040-004-0421-6

Hatton T, Evans R (1998) Dependence of ecosystems on groundwater and its significance to Australia, vol 12/98, Occasional paper. Land and Water Resources Research and Development Corporation, Canberra

Haynes V (2008) Quaternary cauldron springs as paleoecological archives. In: Stevens LE, Meretsky VJ (eds) Aridland springs in North America: ecology and conservation. University of Arizona Press, Tucson

Heitmuller FT, Reece BD (2007) Spatial data for Eurycea salamander habitats associated with three aquifers in south-central Texas. US Geological Survey, Austin, Texas

Hershler R (1998) A systematic review of the hydrobiid snails (Gastropoda: Rissoidea) of the Great Basin, western United States. Part I. Genus Pyrgulopsis. Veliger 41(1):1-132

Hershler R, Liu H-P, Howard J (2014) Springsnails: a new conservation focus in western North America. Bioscience 68:693-700. doi:10.1093/biosci/biu100

Hunt RJ, Krabbenhoft DP, Anderson MP (1996) Groundwater inflow measurements in wetland systems. Water Resour Res 32(3):495-507

Hynes HBN (1970) The ecology of running waters. University of Toronto Press, Toronto

Jayasekera DL, Kaluarachchi JJ, Villholth KG (2011) Groundwater stress and vulnerability in rural coastal aquifers under competing demands: a case study from Sri Lanka. Environ Monit Assess 176(1-4):13-30. doi:10.1007/s10661-010-1563-8

Jin XM, Schaepman ME, Clevers JG, Su ZB, Hu G (2011) Groundwater depth and vegetation in the Ejina area, China. Arid Land Res Manag 25(2):194-199

Johnson RH, DeWitt E, Wirt L, Arnold LR, Horton JD (2011) Water and rock geochemistry, geologic cross sections, geochemical modeling, and groundwater flow modeling for identifying the source of groundwater to Montezuma Well, a natural spring in central Arizona. U.S. Geological Survey Open-File Report 2011-1063, Reston, Virginia

Kolb TE, Hart SC, Amundson R (1997) Boxelder water sources and physiology at perennial and ephemeral stream sites in Arizona. Tree Physiol 17(3):151-160

Kondolf GM (1994) Geomorphic and environmental effects of instream gravel mining. Landsc Urban Plan 28(2-3):225-243. doi:10.1016/0169-2046(94)90010-8

Kray J, Cooper D, Sanderson J (2012) Groundwater use by native plants in response to changes in precipitation in an intermountain basin. J Arid Environ 83:25-34

Kreamer DK, Stevens LE, Ledbetter, JD. Groundwater dependent ecosystems-science, challenges, and policy. In: Adelana SM (ed) Groundwater. Nova Science Publishers, Hauppauge (NY), pp 205-230. ISBN: 978-1-63321-759-1

Kulabako NR, Nalubega M, Thunvik R (2007) Study of the impact of land use and hydrogeological settings on the shallow groundwater quality in a peri-urban area of Kampala, Uganda. Sci Total Environ 381(1-3):180-199. doi:10.1016/j.scitotenv.2007.03.035

Laity JE, Malin MC (1985) Sapping processes and the development of theater-headed valley networks on the Colorado Plateau. Geol Soc Am Bull 96(2):203-217

Lambrakis NJ (1998) The impact of human activities in the Malia coastal area (Crete) on groundwater quality. Environ Geol 36(1-2):87-92

Lamontagne S, Cook PG, O'Grady A, Eamus D (2005) Groundwater use by vegetation in a tropical savanna riparian zone (Daly River, Australia). J Hydrol 310(1):280-293

Lautz LK (2008) Estimating groundwater evapotranspiration rates using diurnal water-table fluctuations in a semi-arid riparian zone. Hydrogeol J 16(3):483-497 
Leaney F, Crosbie R, O'Grady A, Jolly I, Gow L, Davies P, Wilford J, Kilgour P (2011) Recharge and discharge estimation in data poor areas: scientific reference guide. CSIRO: Water for a Healthy Country National Research Flagship, CSIRO

Leblanc M, Leduc C, Razack M, Lemoalle J, Dagorne D, Mofor L (2003a) Applications of remote sensing and GIS for groundwater modelling of large semiarid areas: example of the Lake Chad Basin, Africa. IAHS Publ 278:186-194

Leblanc M, Razack M, Dagorne D, Mofor L, Jones C (2003b) Application of Meteosat thermal data to map soil infiltrability in the central part of the Lake Chad basin, Africa. Geophys Res Lett 30(19):1998. doi:10.1029/2003GL018094

Li F, Lyons T (1999) Estimation of regional evapotranspiration through remote sensing. J Appl Meteorol 38(11):1644-1654

Loheide SP II, Butler JJ Jr, Gorelick SM (2005) Estimation of groundwater consumption by phreatophytes using diurnal water table fluctuations: a saturated-unsaturated flow assessment. Water Resour Res 41(7):W07030

Lv J, Wang XS, Zhou Y, Qian K, Wan L, Eamus D, Tao Z (2012) Groundwater-dependent distribution of vegetation in Hailiutu River catchment, a semi-arid region in China. Ecohydrology 6:142-149

Máguas C, Rascher K, Martins-Loucao A, Carvalho P, Pinho P, Ramos M, Correia O, Werner C (2011) Responses of woody species to spatial and temporal ground water changes in coastal sand dune systems. Biogeosci Discuss 8(1):1591-1616

Martinet MC, Vivoni ER, Cleverly JR, Thibault JR, Schuetz JF, Dahm CN (2009) On groundwater fluctuations, evapotranspiration, and understory removal in riparian corridors. Water Resour Res 45(5):W05425

Massone HE, Martinez DE, Cionchi JL, Bocanegra E (1998) Suburban areas in developing countries and their relationship to groundwater pollution: a case study of Mar del Plata, Argentina. Environ Manage 22(2):245-254. doi:10.1007/s002679900100

McCracken RD (1992) The modern pioneers of the Amargosa Valley. Nye County Press, Tonopah

McLendon T, Hubbard PJ, Martin DW (2008) Partitioning the use of precipitation-and groundwater-derived moisture by vegetation in an arid ecosystem in California. J Arid Environ 72 (6):986-1001

Meinzer OE (1923) Outline of groundwater hydrology with definitions, vol 494, US Geology Survey Water supply paper. U.S. Govt. Print. Off, Washington, 71pp

Melis TS, Phillips WM, Webb RH, Bills DJ (1996) When the blue-green waters turn red: historical flooding in Havasu Creek, Arizona. U.S. Geological Survey water-resources investigations report 96-4059, Tucson, Arizona

Minckley WL, Deacon JE (eds) (1991) Battle against extinction: native fish management in the American West. University of Arizona Press, Tucson

Monroe SA, Antweiler RC, Hart RJ, Taylor HE, Truini M, Rihs JR, Felger TJ (2005) Chemical characteristics of ground-water discharge along the South Rim of Grand Canyon in Grand Canyon National Park, Arizona, 2000-2001. USGS scientific investigations report 2004-5146, Reston, Virginia

Munch DA, Toth DJ, Haung C, Fortich DM, Osburn WL, Phlips EJ, Quinlan EL, Allen MS, Woods MJ, Cooney P, Knight RL, Clarke RA, Knight SL (2006) Fifty-year retrospective study of the ecology of Silver Springs, Florida. St. Johns River Water Management District, Special Publication SJ2007-SP4, Palatka, Florida

Münch Z, Conrad J (2007) Remote sensing and GIS based determination of groundwater dependent ecosystems in the Western Cape, South Africa. Hydrogeol J 15(1):19-28

Muñoz-Reinoso JC (2001) Vegetation changes and groundwater abstraction in SW Doñana, Spain. J Hydrol 242(3-4):197-209. doi:10.1016/S0022-1694(00)00397-8

Nagler PL, Glenn EP, Lewis Thompson T, Huete A (2004) Leaf area index and normalized difference vegetation index as predictors of canopy characteristics and light interception by riparian species on the Lower Colorado River. Agr Forest Meteorol 125(1):1-17 
Nagler PL, Morino K, Didan K, Erker J, Osterberg J, Hultine KR, Glenn EP (2009) Wide-area estimates of saltcedar (Tamarix spp.) evapotranspiration on the lower Colorado River measured by heat balance and remote sensing methods. Ecohydrology 2(1):18-33

Nath B, Lillicrap AM, Ellis LC, Boland DD, Oldham CE (2013) Hydrological and chemical connectivity dynamics in a groundwater-dependent ecosystem impacted by acid sulfate soils. Water Resour Res 49:441-457. doi:10.1029/2012wr012760

Naumburg E, Mata-gonzalez R, Hunter R, McLendon T, Martin D (2005) Phreatophytic vegetation and groundwater fluctuations: a review of current research and application of ecosystem response modeling with an emphasis on great basin vegetation. Environ Manage 35 (6):726-740. doi:10.1007/s00267-004-0194-7

Newell DL, Crossey LJ, Karlstrom KE, Fischer TP, Hilton DR (2005) Continental-scale links between the mantle and groundwater systems of the western United States: evidence from travertine springs and regional He isotope data. GSA Today 15(12):4-10

Nickerson MA, Mays CE (1973) The hellbenders: North American "giant salamanders", vol 1. Milwaukee Public Museum, Milwaukee

Nilsson C, Reidy CA, Dynesius M, Revenga C (2005) Fragmentation and flow regulation of the world's large river systems. Science 308(5720):405-408

O'Grady A, Cook P, Howe P, Werren G (2006) Groundwater use by dominant tree species in tropical remnant vegetation communities. Aust J Bot 54(2):155-171

Phillips DL, Gregg JW (2003) Source partitioning using stable isotopes: coping with too many sources. Oecologia 136(2):261-269

Pimentel D, Houser J, Preiss E, White O, Fang H, Mesnick L, Barsky T, Tariche S, Schreck J, Sharon A (1997) Water resources: agriculture, the environment, and society. BioScience 47 (2):97-106. doi:10.2307/1313020

Querejeta JI, Estrada-Medina H, Allen MF, Jiménez-Osornio JJ (2007) Water source partitioning among trees growing on shallow karst soils in a seasonally dry tropical climate. Oecologia 152 (1):26-36

Ramstead KM, Allen JA, Springer AE (2012) Have wet meadow restoration projects in the Southwestern US been effective in restoring geomorphology, hydrology, soils, and plant species composition? Environ Evid 1(1):11

Razowska L (2001) Changes of groundwater chemistry caused by the flooding of iron mines (Czestochowa Region, Southern Poland). J Hydrol 244(1-2):17-32. doi:10.1016/S0022-1694 (00)00420-0

Ritsema CJ, Groenenberg JE, Bisdom EBA (1992) The transformation of potential into actual acid sulphate soils studied in column experiments. Geoderma 55(3-4):259-271. doi:10.1016/00167061(92)90087-N

Schirmer M, Reinstorf F, Leschik S, Musolff A, Krieg R, Strauch G, Molson JW, Martienssen M, Schirmer K (2011) Mass fluxes of xenobiotics below cities: challenges in urban hydrogeology. Environ Earth Sci 64(3):607-617. doi:10.1007/s12665-010-0880-0

Scott ML, Shafroth PB, Auble GT (1999) Responses of riparian cottonwoods to alluvial water table declines. Environ Manage 23(3):347-358. doi:10.1007/s002679900191

Scott RL, Cable WL, Huxman TE, Nagler PL, Hernandez M, Goodrich DC (2008) Multiyear riparian evapotranspiration and groundwater use for a semiarid watershed. J Arid Environ 72 (7): $1232-1246$

Shafroth PB, Stromberg JC, Patten DT (2000) Woody riparian vegetation response to different alluvial water table regimes. West N Am Naturalist 60(1):66-76

Shepard WD (1993) Desert springs - both rare and endangered. Aquat Conserv 3(4):351-359

Spałek K, Pro ków J (2011) Karst springs as habitats for rare and protected plant species: a new inland locality of a halophyte plant Batrachium baudotii (Ranunculaceae) in a karst spring in Central Europe. J Cave Karst Stud 73:158-162

Springer AE, Stevens LE (2009) Spheres of discharge of springs. Hydrogeol J 17(1):83-93

Springer AE, Stevens LE, Anderson DE, Parnell RA, Kreamer DK, Levin L, Flora S (2008) A comprehensive springs classification system: integrating geomorphic, hydrogeochemical, and ecological criteria. In: Stevens LE, Meretsky VJ (eds) Aridland springs in North America: ecology and conservation. University of Arizona Press, Tucson 
Springs Stewardship Institute (2012) Springs ecosystem inventory, assessment, and stewardship. Available on-line at: www.springstewardship.org. Accessed 1 Mar 2014

Stacey CJ, Springer AE, Stevens LE (2011) Have arid land springs restoration projects been effective in restoring hydrology, geomorphology, and invertebrate and plant species composition comparable to natural springs with minimal anthropogenic disturbance? CEE review 10002. Collaboration for Environmental Evidence. www.environmentalevidence.org/SR87.html

Stevens LE, Ledbetter JD (2012) Ecohydrology of springs on Kaibab National Forest to support forest planning. Springs Stewardship Institute, Flagstaff

Stock WD, Bourke L, Froend RH (2012) Dendroecological indicators of historical responses of pines to water and nutrient availability on a superficial aquifer in south-western Australia. For Ecol Manage 264:108-114

Thorburn PJ, Hatton TJ, Walker GR (1993) Combining measurements of transpiration and stable isotopes of water to determine groundwater discharge from forests. J Hydrol 150(2):563-587

Tweed SO, Leblanc M, Webb JA, Lubczynski MW (2007) Remote sensing and GIS for mapping groundwater recharge and discharge areas in salinity prone catchments, southeastern Australia. Hydrogeol J 15(1):75-96

U.S. Forest Service (2012) Groundwater-dependent ecosystem inventory using remote sensing. RSAC-10011-RPT1. Remote Sensing Evauation, Applications \& Training Center, Salt Lake City, Utah

Unmack PJ, Minckley WL (2008) The demise of desert springs. In: Stevens LE, Meretsky VJ (eds) Aridland springs in North America: ecology and conservation. University of Arizona Press, Tucson, pp 11-34

Vörösmarty CJ, Green P, Salisbury J, Lammers RB (2000) Global water resources: vulnerability from climate change and population growth. Science 289(5477):284-288. doi:10.1126/sci ence.289.5477.284

Wada Y, van Beek LPH, van Kempen CM, Reckman JWTM, Vasak S, Bierkens MFP (2010) Global depletion of groundwater resources. Geophys Res Lett 37(20), L20402. doi:10.1029/ $2010 \mathrm{~g} 1044571$

Wang GX, Cheng GD, Du MY (2003) The impacts of human activity on hydrological processes in the arid zones of the Hexi Corridor, northwest China, in the past 50 years. IAHS-AISH P 280:93-103

Weber K, Perry R (2006) Groundwater abstraction impacts on spring flow and base flow in the Hillsborough River Basin, Florida, USA. Hydrogeol J 14(7):1252-1264. doi:10.1007/s 10040006-0040-5

White WN (1932) A method of estimating ground-water supplies based on discharge by plants and evaporation from soil: results of investigations in Escalante Valley, Utah. Water supply paper 659-A. US Geological Survey, Utah

Winograd IJ, Riggs AC, Coplen TB (1998) The relative contributions of summer and cool-season precipitation to groundwater recharge, Spring Mountains, Nevada, USA. Hydrogeol J 6(1):77-93

Younger P, Wolkersdorfer C (2004) Mining impacts on the fresh water environment: technical and managerial guidelines for catchment scale management. Mine Water Environ 23(1):s2-s80. doi:10.1007/s10230-004-0028-0

Zektser S, Loáiciga HA, Wolf JT (2005) Environmental impacts of groundwater overdraft: selected case studies in the southwestern United States. Environ Geol 47(3):396-404. doi:10.1007/s00254-004-1164-3

Zencich SJ, Froend RH, Turner JV, Gailitis V (2002) Influence of groundwater depth on the seasonal sources of water accessed by Banksia tree species on a shallow, sandy coastal aquifer. Oecologia 131(1):8-19

Zeppel MJ, Macinnis-Ng CM, Yunusa IA, Whitley RJ, Eamus D (2008) Long term trends of stand transpiration in a remnant forest during wet and dry years. J Hydrol 349(1):200-213 